\title{
CSALÁDI HÁZ ALTERNATÍV ENERGIAELLÁTÁSA
}

\section{ALTERNATIVE ENERGY USE OF A RESIDENTIAL HOUSE}

\author{
Kovács Ágota \\ Debreceni Egyetem Müszaki Kar Müszaki Menedzsment és Vállalkozási Tanszék, \\ Cím: 4028, Magyarország, Debrecen, Ótemetö utca 2-4., Tel.: +36 (52) 415-415, \\ kovacs.agota94@gmail.com
}

\begin{abstract}
Nowadays, alternative energy use receives more and more attention. Price increase of fossil fuels and environmentally friendly lifestyle inspire owners of residential houses to invest in alternative systems. This study examines how cost-effective it is, - in case of a residential house,- to invest in solar systems, (without any grant subsidy).

Keywords: alternative energy, solar panel, cost-effectiveness

\section{Összefoglalás}

Az alternatív energiafelhasználás napjainkban egyre inkább előtérbe kerül. A fosszilis energiahordozók árának emelkedése, a környezettudatos életmód arra ösztönzik a családi házak tulajdonosait, hogy megújuló energiával müködő rendszerekbe ruházzanak be. A tanulmányunkban azt vizsgáltuk, hogy egy családi ház esetében mennyire költséghatékony önerőböl - pályázati támogatás nélkül - napenergiás rendszerbe beruházni.
\end{abstract}

Kulcsszavak: alternatív energia, napelem, költséghatékonyság

\section{Bevezetés}

Rohamosan fejlődő világunkban egyre nagyobb figyelmet kap az alternatív energia használata. A XXI. században a fosszilis energiahordozók kimerülése, ezek emelkedő árai, valamint a használatukból adódó környezetszennyezés, egyre inkább arra ösztönzik a lakosságot, hogy környezettudatosan éljenek, valamint takarékoskodjanak az energiával.

Egyre több családi ház tulajdonosa gondolkozik el azon, milyen alternatív módon tudná csökkenteni az épület rezsiköltségeit, és hogyan növelhetné az energiahatékonyságot. Ehhez próbálunk segítséget nyújtani gazdaságossági számítással, költségelemzéssel.

\section{Alternatív energiahasználat le- hetőségei családi házaknál}

Magyarországi családi házak esetében a következő alternatív energiák használata kerülhet szóba:

- napenergia (napelem, napkollektor)

- szélenergia (szélgenerátor)

- geotermikus energia (hőszivattyúk)

- biomassza (pellettkazán)

Magyarországon egyre több vállalkozó szellemü háztulajdonos telepít családi házának tetejére napkollektort vagy napelemet.

Magyarország adottságai a napenergiahasznosítás szempontjából kedvezőek, az évi napsütéses órák száma: 1900-2200, a beeső napsugárzás éves összege átlagosan 
$1300 \mathrm{kWh} / \mathrm{m} 2$ [1]. A MEKH adatai szerint, a háztartási méretü kiserőmüvek száma 2013 óta évröl évre duplázódik. 2015 végén mintegy $15136 \mathrm{db}$ háztartási méretü naperőmü csatlakozott a villamosenergiahálózatra [2].

\section{A vizsgált beruházás előzményei}

\subsection{A családi ház adatai}

A Hajdúszoboszlón 1986-ban épült téglaépítésü családi ház hasznos alapterülete $143 \mathrm{~m}^{2}$. A tulajdonos a homlokzatot $5 \mathrm{~cm}$ vastag expandált polisztirol táblákkal, a födémet pedig $25 \mathrm{~cm}$ vastag üveggyapottal szigetelte a 2000-es évek elején. Tapasztalata szerint az energiaköltségek (áram-, gázszámla) így 40\%-kal csökkentek. 2009ben a fa nyílászárókat, háromrétegü müanyag ablakokra cserélte ki. Ez mintegy 1015\%-os energiacsökkentéshez vezetett

A lakásban tartósan élők száma 2 fó, évente 1 hónapra 5 före bővül.

\subsection{Napelemes beruházás indokai}

A tulajdonos az alábbiak miatt kezdett a fotovillamos elemek beruházásába:

- az épületet így magasabb energiaosztályba lehet besorolni;

- környezettudatosság;

- a villamos energiafogyasztását részben/teljesen ki lehet váltani megújuló energiaforrások felhasználásával müködő termelö berendezéssel, illetve az elszámolási időszakban keletkező többlettermelés értékesítése;

- véleménye szerint nem igényel karbantartást a napelemes rendszer;

- öt éves megtérüléssel számolt;

- rendelkezett a beruházáshoz szükséges tökével [3].

\section{Költségek és számítások}

A költségeket és a beruházás időbeni megtérülését vizsgáltuk

\subsection{Energiaköltségek}

A családi ház éves gázfogyasztása a beruházás elötti időszakban: $2100 \mathrm{~m}^{3} / \mathrm{h} * 120 \mathrm{Ft} / \mathrm{m}^{3}=252.000 \mathrm{Ft} / \mathrm{e} \mathrm{v}$

Korábbi éves villamos áramfogyasztás: 2746,7 kW*50,97 Ft/kW=140.000 Ft/év.

Ekkor üzemelö készülékek:

- $1 \mathrm{db}$ Ariston Clas Premium EVO 24FF gázkazán (24 kW, 2,8 m³ /óra);

-általános háztartási elektromos berendezések, klíma még nem volt.

\subsection{Beruházási költségek}

A családi ház tulajdonosa 2015 elején $21 \mathrm{db}$ napelem (5 kWp-os rendszer) megvásárlása mellett döntött. $\mathrm{A}$ fotovillamos rendszert a lakóház és a mellette lévő melléképület tetejére építtette ki.

Az 1. táblázat mutatja, hogy a napelemes rendszer megvásárlása és telepítése folyamán és azt követően milyen költségei merültek fel a tulajdonosnak.

1. táblázat. A beruházási költségek (Forrás: saját szerkesztés)

\begin{tabular}{|l|r|r|}
\hline Megnevezés & Mennyiség (db) & Ár (Ft) \\
\hline $\begin{array}{l}\text { Napelem (Trina típusú polikristályos) teljesítménye } \\
240 \mathrm{~W}\end{array}$ & 21 & 1.080 .000 \\
\hline $\begin{array}{l}\text { Inventer (FRONIUS IG TL 5 tịp.) névleges } \\
\text { teljesitménye 5040 W }\end{array}$ & 1 & 232.500 \\
\hline Szerelési anyagok, biztonsági szerelvények & & 310.000 \\
\hline Szerelési költség & & 180.865 \\
\hline Villanybojler (Ariston Velis VLS 100 Erp) & 1 & 61.999 \\
\hline Szerelési költség, anyagok & 1 & 182.880 \\
\hline Klima (LG E09EM Comfort inverteres split) & 1 & 249.935 \\
\hline $\begin{array}{l}\text { Klima (Samsung AR09 HSFSBWKNZE Good2 } \\
\text { inverteres split) }\end{array}$ & & \\
\hline Szerelési költség, anyagok & & $\mathbf{2 . 4 5 8 . 1 7 9}$ \\
\hline Összesen+ ÁFA & & \\
\hline
\end{tabular}

A napelemes rendszer üzembe helyezése után:

A fotovillamos cellák által egy év alatt termelt energia: $4215 \mathrm{~kW} /$ év. Ez jóval több, mint amennyire szüksége volt korábban a tulajdonosnak. A tulajdonos korábban azt tervezte, hogy a többletenergiát eladja az áramszolgáltatónak. Erre egyszer, az éves 
leolvasás után kerül sor. Ehhez számlaképesnek kell lenni valamint adózni kell a bevétel után. A családi ház tulajdonosa, csak utólag, a napelemek megvásárlása után szembesült ezzel a ténnyel. Mivel nem volt számlaképes, ezért új, elektromos eszközöket vásárolt, hogy a megtermelt, többletenergiát felhasználja. (Itt fontos megjegyezni, hogy ne legyen túlméretezett a napelemes rendszer.)

Újonnan használatba vett eszközök:

- $1 \mathrm{db}$ 2,5 kW-os hütő-fütő klíma és $1 \mathrm{db} 3$ kW-os hütő-fütő klíma.

- 1 db villanybojler (a gázkazánt vízmelegítésre nem használják)

A klímákat az első évben csak hütésre használták. Az első év végén a villanyóra leolvasásakor 729,4 Kw/h $(13.100 \mathrm{Ft})$ többlettermelése volt a tulajdonosnak. Ekkor döntött úgy, hogy a klímákkal füteni is fog. A gázkazán így december 1 - február 15-ig van használatban, a gázfogyasztásuk jelenleg $850 \mathrm{~m}^{3} / \mathrm{é}^{*} * 120 \mathrm{Ft} / \mathrm{m}^{3}=102.000 \mathrm{Ft} / \mathrm{év}$

$\mathrm{Az}$ inverteres klímaberendezések fütésre -15 ${ }^{\circ} \mathrm{C}$-os külső hőmérsékletig működtetehetőek biztonságosan. A két klímaberendezés nem tudja az épület alsó szintjét felmelegíteni, ezért kiegészítő fütésre (gázfütésre) sokszor szükség van.

\subsection{Megtérülés számítás}

Az éves energiamegtakarítás a következő módon adódik: Megtakarítás = gázfogyasztás különbözete + elektromos fogyasztás különbözete $(+$ az elektromos többlettermelés értékesítése). Számokkal:

Régi gázfogyasztás- új éves gázfogyasztás: $252.000 \mathrm{Ft}-102.000 \mathrm{Ft}=150.000$ Ft/év.

Régi áramszámla: $140.000 \mathrm{Ft} / \mathrm{e} v$, jelenleg 0 Ft. Az éves megtakarítás 303.100 Ft.

A számításunkhoz Bánóczy és szerzőtársai által is alkalmazottak szerinti készítettük el [4] nettó jelenérték (NPV) számítás. Ezzel az eljárással a projekt hasznos élettartalma során történő pénzmozgások hasonlíthatók össze és ezek összegezhetők is. A nettó jelenérték egy adott kamatláb melletti diszkontált jövedelmet jelent. A számításnál figyelembe vettem, hogy a beruházás utáni minden 10 . évben egy új inventert kell vásárolni, ugyanis az inverter élettartalma körülbelül ennyi időt tesz ki. Ezen felül a klímákat minden évben karbantartani, tisztítani kell, ami plusz kiadást jelent [5].

Egy beruházás nettó jelenértéke a megvalósítás T0 időpontjában egyenlő a beruházáshoz kapcsolódó nettó pénzáramok nettó jelenértékével:

$N P V=-I_{0}+\sum_{i=1}^{n}\left(R_{i}-D_{i}\right)(1+t)^{-i}+V_{n}(1+t)^{-n}$

ahol:

$-\mathrm{n}=\mathrm{a}$ projekt élettartam periódusainak (éveinek) száma

$-\mathrm{I}_{0}=$ kezdő pénzáram $\mathrm{T}_{0}$ időpontban (a beruházás megvalósítási költsége),

$-\mathrm{Ri}=\mathrm{az}$ i. periódus müködési bevétele (hozama),

$-\mathrm{D}_{\mathrm{i}}=$ az i. periódus müködési kiadásai,

$-\mathrm{R}_{\mathrm{i}}-\mathrm{Di}=\mathrm{az}$ i. periódus nettó cash flow-ja, $-\mathrm{t}=$ diszkontráta,

$-\mathrm{V}_{\mathrm{n}}=\mathrm{a}$ beruházás maradványértéke Tn időpontban.

A beruházás megtérülö, ha az NPV > 0 [6].

\section{Eredmények}

A számítások eredményeit a 2 . táblázat és az 1. ábra szemlélteti.

2. táblázat. Napenergia megtermelése (Forrás: saját szerkesztés)

\begin{tabular}{|r|r|r|r|r|r|r|}
\hline Évek & Bevétel & Kiadás & kiadás & diszfakt & diszk hoz & cumdiszkhoz \\
\hline 0 & 0 & 2458179 & -2458179 & 1 & -2458179 & -2458179 \\
\hline 1 & 290000 & 30000 & 260000 & 0,9709 & 252427,1845 & $-2205751,8155$ \\
\hline 10 & 264920 & 400000 & -135080 & 0,7441 & $-100512,2060$ & $-612976,9944$ \\
\hline 11 & 262271 & 552815 & -290544 & 0.7224 & -209895.1674 & -822871.8618 \\
\hline 16 & 249417 & 30000 & 219417 & 0,6232 & 136733,4203 & $-79595,9318$ \\
\hline 17 & 246923 & 30000 & 216923 & 0,6050 & 131241,9825 & 51646,0507 \\
\hline
\end{tabular}




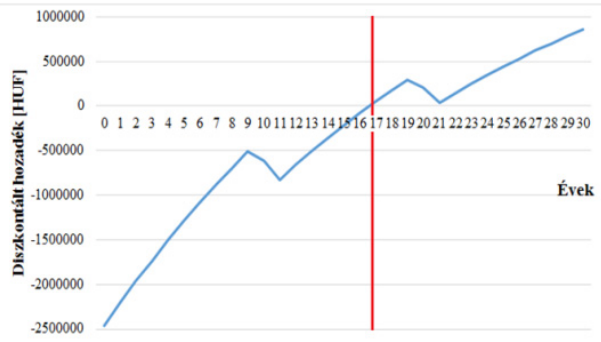

1. ábra. Napelemes rendszer megtérülésének ideje grafikonnal ábrázolva (Forrás: saját szerkesztés)

Az 1. ábra jól szemlélteti, hogy a megtérülés legjobb esetben 16,5 évnél lesz, ha nem számoljuk az inflációt és az áram átvételi díjak változását. Minden 11. évben törés látható, amelyek az inverter cseréje miatt keletkezik. Ha a klímákat hütésre és fütésre is egyaránt használjuk, akkor az alkatrészek gyorsabban használódnak el, ezért a karbantartásra, tisztításra különösen oda kell figyelni (évi kb. 20.000 Ft). A fogyasztónak számolnia kell a napelemek esetleges meghibásodásával, ezek javítása olyan plusz költségként merül fel, amellyel nem lehet elöre tervezni és számolni. A napelem rendszerek összteljesítménye mindig a leggyengébben teljesítő napelemtől függ. Ezért is fontos, hogy ne érje a paneleket árnyék, ne legyen rajtuk szennyeződés. Folyamatos figyelmet, karbantartást igényelnek.

Mindezek mellett a napelemek évi $1 \%$ os degradációját is figyelembe kell venni (2. táblázat). Elemi károk (villámcsapás, jégeső) is érhetik a napelemes rendszert. Lehet rá biztosítást kötni, bár így a megtérülési idő növekedni fog.

\section{Következtetések}

A családi házak energiafogyasztása minden évben jelentős összegbe kerül. Cikkünkben megvizsgáltuk, hogy egy családi ház esetében hogyan tudnánk ezeket az összegeket alternatív energia (napenergia) segítségével csökkenteni. Meggyőződésünk szerint számlaképesség hiányában különösen figyelnünk kell arra, hogy csak olyan napelemes rendszert építsünk ki, amely nincs túlméretezve. A beruházóknak a felmerülö többletköltségekkel (javítás, karbantartás, a rendszer degradációja) is számolni kell. A napelemes rendszerek telepítése előtt érdemes konzultálni szakemberrel, tisztában kell lenni a jogszabályi háttérrel (engedélyeztetés, elszámolás az áramszolgáltató felé, adózás).

Amennyiben nem rendelkezünk, megfelelő alaptőkével vagy tovább szeretnénk csökkenteni a beruházási költségeinket érdemes a kormány által meghirdetett pályázatokat igénybe venni, amelyek segítségével a megtérülési idő akár a felére is csökkenhet.

\section{Szakirodalmi hivatkozások}

[1] Farkas, I.: A napenergia hasznositásának hazai lehetöségei. In.:Magyar Tudomány. 2010. 8. sz. p. 937-946.

[2] Összefoglaló a nem engedélyköteles - ezen belül a háztartási méretü kiserömüvek adatairól. In.: $\quad$ http://enhat.mekh.hu/wpcontent/uploads/2015/10/osszefoglalo_nem e ngedelykoteles kiseromuvek_adatairol.pdf (Letöltés ideje: 2017.02. 11.)

[3] Kovács, Á., Jenei T.: Napenergia használata villamosáram termelésre egy családi házon vizsgálva In: International Journal of Engineering and Management Sciences (IJEMS) Vol.1. (2016). No.1.

[4] Bánóczy, E. [et al]: Simulation of building renovation's returninenergy plus, In: Environmental Engineering and Management Journal 13: (11) 2014. pp. 2743-2748.

[5] Napelem inverterek In: http://napeleminverter.hu/ (Letöltés ideje: 2017.02.05. 17:48)

[6] Pucsek, J. : Pénzügyi és számviteli kontrolling, In: http://www.tankonyvtar.hu/hu/tartalom/tamo p412A/0007_e7_penzugyi_es_szamviteli_ko ntrolling_scorm/netto_jelenertek_npv_s $\bar{B}$ T MLDyvGqy1Dp5a.html (Letöltés ideje: 2017.02.07 16:53) 